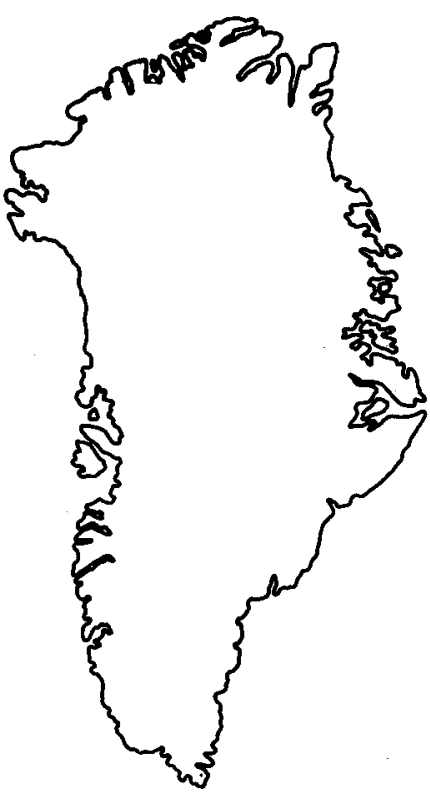

\section{A new ruedemannoceratid cephalopod from the Ordovician of western North Greenland}

\author{
Rousseau H. Flower
}

Peeloceras, a new Ordovician (Chazy) genus of the family Ruedemannoceratidae (Cephalopoda), is described from the Cape Webster Formation of Washington Land, western North Greenland, with type species $P$. websterense n. gen. n. sp.

R.H.F. New Mexico Bureau of Mines \& Mineral Resources, Socorro, New Mexico 87801, U.S.A.

The Cape Webster Formation of southern Washington Land, western North Greenland, was proposed by Koch (1929) for a sequence of $290 \mathrm{~m}$ of light grey or yellow, very hard limestone interstratified with dark grey shaly limestone which occurred between the highly fossiliferous Nunatami and Gonioceras Bay Formations. Recent fieldwork has demonstrated that the formation is largely composed of pale weathering, thin bedded dolomite with interbedded siltstones and anhydritic horizons (Peel, 1977).

Fossils are rare in the Cape Webster Formation. Previously, the principal evidence for its inferred age has been its stratigraphic position between the Late Canadian (Early Ordovician) Nunatami Formation and the Gonioceras Bay Formation of Black River (Middle Ordovician) age. However, Troedsson (1926) described a specimen tentatively identified as Protocycloceras lamarcki from the Cape Webster Formation, indicative of Late Canadian age. He was subsequently prompted to question this assignment and suggest a younger, Chazy (early Middle Ordovician), age due to the presence of crinoid stems (Troedsson, 1928, p. 147-8). Teichert (1937) compared Troedsson's specimen to Spyroceras geronticum, a much later Ordovician species, but concluded that the material probably represented a new species.

Without knowledge of the siphuncle generic assignment of the species is impossible. The Cape Webster lies above the Nunatami Formation which is of late and probably latest Canadian age on the basis of Hintze's (1953) identification of some species from his zones J and $\mathrm{K}$ of western Utah in terms of species described from the Nunatami by Poulsen (1927). V.E. Kurtz (Springfield, Missouri, pers. comm. to J.S. Peel, GGU) considers conodonts from the highest Nunatami to lie very close to the Canadian-Whiterock boundary. The overlying Gonioceras Bay Formation lies certainly within the limits of the Wilderness Stage of Cooper (1956) which includes beds formerly considered as Black River with the addition of the Rockland, previously considered 
lower Trenton, and is quite probably equivalent to the Chaumont Limestone of north-western New York. Between these formations two genera of annulated orthocones are known. If Troedsson's specimen has longitudinal markings and expanded siphuncle segments, it is assignable to the genus Stereospyroceras, thus far known only from the Chazyan. However, if it is without fine markings or has transverse ones, and has a tubular siphuncle, the species would be assignable to Aethiosolen, a genus known only from the Whiterock Stage. A third possibility is assignment to Tofangoceras Kobayashi, an annulated orthocone with transverse markings or none, and expanded siphuncle segments. This genus is known from beds ranging from Chazyan in age in the North China Plate, up into the Black River of north-western New York and adjacent Ontario.

Troelsen (1950) located ostracodes near the base of the Cape Webster Formation but was unable to add to Troedsson's suggestion of a possible Chazyan age.

In 1976 a second orthoconic cephalopod (MGUH 14252 from GGU collection 206360) was collected from the Cape Webster Formation at Nygaard Bugt by John S. Peel (GGU), about 80 $\mathrm{m}$ below the junction with the overlying Gonioceras Bay Formation. Conodonts from the same sample indicate a Chazyan age (V.E. Kurtz, pers. comm. to J.S. Peel, GGU). This specimen was an orthocone weathered from the upper side, which later proved to be the true dorsum, to the level of the siphuncle, the latter consisting of moderately expanded segments. It was later ground from the weathered surface to attain as close to the centre of the siphuncle segments as could be ascertained. At first glance, the specimen seemed attributable to Allumettoceras. With closer study this assignment had to be rejected because the siphuncle segments are much larger in proportion to the width of the shell, and because a cross section at the anterior end of the specimen shows the ventral wall of the shell to be gently convex rather than perfectly flat. Instead, it was recognized that this species represents a new genus belonging to the Ruedemannoceratidae. In spite of the limitations of the specimen, it was finally decided to name it, as it is described below.

\section{Genus Peeloceras Flower n. gen.}

Genotype. Peeloceras websterense Flower, n. sp.

Description. The shell is orthoconic or very slightly endogastrically curved. In cross section the venter is gently rounded, sides become strongly rounded, and the unknown dorsum is probably broadly arched. Septa are deeply curved at the level of the siphuncle which is close to the venter; ventral lobes can be clearly inferred; probably elsewhere the sutures were transverse or nearly so. The siphuncle lies close to the venter, but is narrowly separated from it; its segments are broadly rounded, about twice as broad as long at the septal foramen, to half again the minimal width, which is almost one-third the width of the shell. Septal necks are gently recurved, free, very much as in Ormoceras on the dorsum and at the sides, and are certainly free also on the ventral side. Episeptal deposits occur in the more apical camerae of the genus.

Discussion. This genus is assigned to the Ruedemannoceratidae on the basis of the similarities between it and four genera as yet unpublished. Ruedemannoceras is a more strongly curved genus, depressed in section, with simple sutures and a subcentral siphuncle of broadly expanded segments. It is known from the Chazyan of the Champlain Valley and from the Murfreesboro Limestone of Central Tennessee, which may be as young as the lower Wilderness Stage of 
Cooper (1956). Franklinoceras is similar, except for a compressed cross section and tranverse sutures which slope forward on the convex side; it is known from the Chazy of the Champlain Valley and a Chazyan faunule from the Seward Penninsula of Alaska. Longanoceras, a genus known only from the Table Head Formation of Newfoundland of Whiterock age, is similar to Ruedemannoceras, but slightly more slender, with the siphuncle closer to the dorsum than to the venter. Madiganella, known from the Ordovician of Australia from faunas of Chazy or slightly younger age, is a more slender shell, the section more flattened on the venter and more broadly arched on the dorsum, faintly endogastric to straight. Its siphuncle is subcentral, segments are like those of our present genus in form, with necks sharply recurved but very short.

More similar to our present genus are four others as yet unpublished. All of them agree with our present genus in that the siphuncle is quite close to the venter. Their shells are straight or faintly endogastric, but quite slender. They differ in that the segments are more sharply expanded, the brims being recumbent and adnate to the septa at least on the dorsum, and there is a broad area of adnation of the apical end of the ring on the venter. One such form is from the McLish Limestone of Oklahoma which is clearly of Chazyan age. Three others are from the Coolibah Formation of the Nora Range of western Queensland, Australia.

The age of the Coolibah Formation is not yet determined accurately in relation to the American sections. It contains Teichispira and Clitendoceras, formerly known only from beds of Late Canadian age, but it also contains many more advanced forms, including endoceroids related to Williamsoceras, Cacheoceras and Rossoceras, a series of actinoceroids including apparent Armenoceras and the remarkable family Georginidae (Wade, 1977), so advanced beyond any Canadian faunas that an age older than the Whiterock Stage is impossible.

\section{Peeloceras websterense Flower, n. sp.}

Fig. 1

Description. The single specimen from which this species is known is an orthoconic cephalopod, showing $52 \mathrm{~mm}$ of phragmocone expanding in width from an estimated $19 \mathrm{~mm}$ to $24 \mathrm{~mm}$, and preserves eithteen siphuncle segments with septa and parts of the shell wall. An anterior cross section shows the venter to be gently convex in cross section and shows no septa or siphuncle, and thus probably represents the base of the living chamber. The siphuncle at the base shows segments, three occurring in a length of $8 \mathrm{~mm}$, expanding laterally from 4.0 to $5.2 \mathrm{~mm}$. Adorally segments are shorter and broader, two occur in a length of $5 \mathrm{~mm}$, and expand from 5.0 to 7.5 mm laterally. Septa are curved, their horizontal depth being equal to one and a half camerae. Apically, episeptal deposits are developed, but thin rapidly forward, and can be recognized only in the basal five camerae.

Discussion. Though only the ventral part of the shell is preserved, there is enough here to distinguish this as a distinct species and genus as noted under the generic discussion.

Preservation is poor. All calcareous materials have been dissolved and replaced by material similar to the matrix except that it is dark grey rather than tan in colour. The outline of the siphuncle segments is clearly shown, and prior to grinding, the dorsal surface of the siphuncle showed clearly that the septal necks were free and not recumbent as in the other most similar forms known. Differentiation of rings and neck as well as the original textural differences which are 


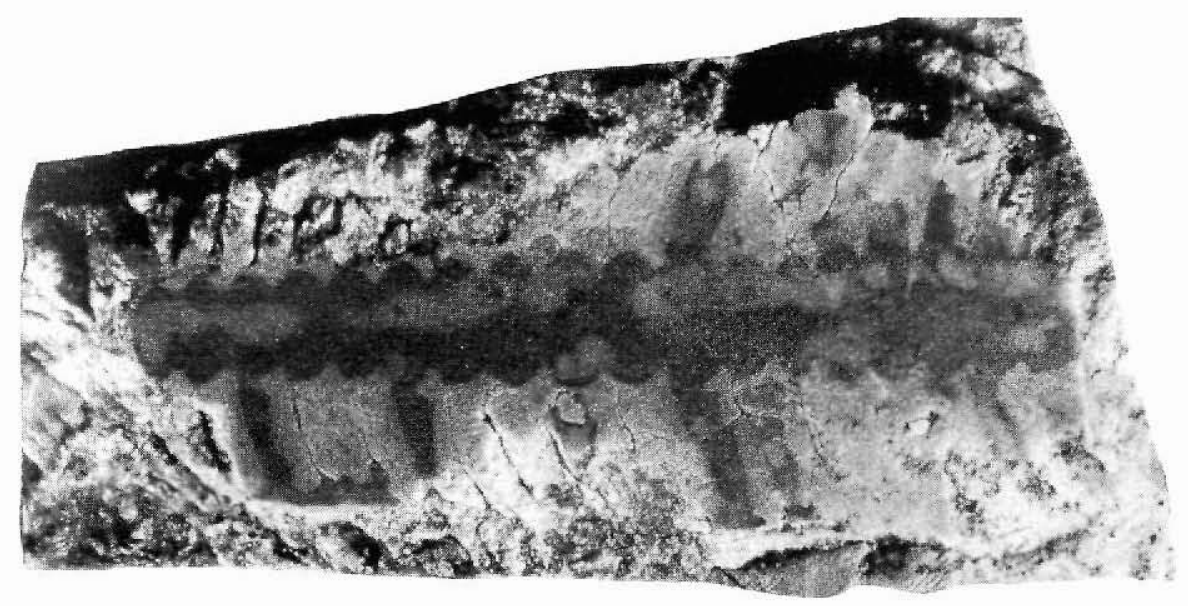

Fig. 1. Peeloceras websterense Flower n. gen. n. sp., holotype, MGUH 14252 from GGU collection 206360, Cape Webster Formation, Washington Land. Transverse Iongitudinal section, $\times 2$.

universal in the rings of the older Discosorida are lost. Mottling within the siphuncle is irregular, though the eighth segment shows a pattern, obviously achieved by chance, suggesting a central canal and radial canals like those of Ormoceras and allied actinoceroids. Near the apical end of the specimen, the right side shows the episeptal deposits weathered; on the opposite side they are represented by dark grey material. Irregular splotches of dark grey material occur erratically in anterior camerae. The dark grey material represents original shell parts plus a considerable amount of inorganic calcite both in the camerae and siphuncle.

We were at first reluctant to name this species and genus, but realized that it may be many years before a second and better specimen can be obtained from the Cape Webster Formation. There is enough shown here for comparison with any future finds of more complete specimens either of this species or of possible congeneric specimens from other regions or horizons.

The species and genus suggest most strongly assignment of the Cape Webster Formation within the limits of the Whiterock and Marmor (Chazy) of Cooper (1956), an age assignment in agreement with that suggested by V.E. Kurtz after preliminary examination of conodonts from a few, scattered samples.

\section{References}

Cooper, G.A. 1956: Chazyan and related brachiopods. Smithson. Misc. Collns 127, 1245 pp.

Hintze, L.F. 1953: Lower Ordovician Trilobites from western Utah and eastern Nevada. Bull. Utah geol. miner. Surv. 48, 249 pp.

Koch, L. 1929: The geology of the south coast of Washington Land. Meddr Gronland 73(1), $39 \mathrm{pp}$.

Peel, J.S. 1977: Cambrian-Silurian studies in Washington Land, western North Greenland. Rapp. Grønlands geol. Unders. 85, 30-33.

Poulsen, C. 1927: The Cambrian, Ozarkian and Canadian faunas of northwest Greenland. Meddr Gronland $70(2), 236-343$. 
Teichert, C. 1937: Ordovician and Silurian faunas from Arctic Canada. Rept. 5th Thule Expedition 1921-24 1(5), $165 \mathrm{pp}$.

Troedsson, G. 1926: On the Middle and Upper Ordovician faunas of northern Greenland. I. Cephalopods. Meddr Grønland 71, 1-157.

Troedsson, G. 1928: On the Middle and Upper Ordovician faunas of northern Greenland II. Meddr Grønland 72(1), 1, $197 \mathrm{pp}$.

Troelsen, J.C. 1950: Contributions to the geology of Northwest Greenland, Ellesmere Island and Axel Heiberg Island. Meddr Grønland 149(7), 149 pp.

Wade, M. 1977: Georginidae, a new family of actinoceratoid cephalopods, Middle Ordovician, Australia. Mem. Queensland Mus. 18, 1-15. 